\title{
Some cases of regrammaticalization in Tupí-Guaraní languages
}

Aryon Dall'Igna Rodrigues

\section{Resumo}

Apresento uma discussão sobre algumas mudanças morfossintáticas devidas a causas linguísticas ou sociais, ou de ambas naturezas, durante o desenvolvimento histórico de algumas línguas Tupí-Guaraní.

Palavras-chave: Tupí-Guaraní, morfossintaxe, linguística histórica, mudança linguística.

\begin{abstract}
I present a discussion on some cases of morpho-syntactic changes due to linguistic or social causes, or both, during the past historical development of some Tupí-Guaraní languages.
\end{abstract}

Keywords: Tupí-Guaraní, morphosyntax, historical linguistics, linguistic change.

\section{Introduction ${ }^{1}$}

On the basis of more conservative languages of the Tupí-Guaraní linguistic family (such as Tupinambá, Old Guaraní, Kamayurá, Parintintín) it is possible to reconstruct some grammatical properties of Proto-Tupí-Guaraní - the pre-historical common ancestor of this family - and to observe several cases of regrammaticalization that have contributed to the differentiation in the realm of this language family. My aim in this paper is to present and to discuss in a very preliminary way a few instances of such morphosyntactic changes.

Tupí-Guaraní is a close-knit linguistic family even though it is a very widespread group of languages. With about 40 languages, it extends from the eastern coast of Brazil to the foothills of the Bolivian Andes and from French Guyana in the north to Argentina in the south. Both lexically and morphologically its languages share a high percentage of features, and their phonologies are not strongly divergent (Rodrigues 1985, Dietrich 1990). Only a very few languages, such as Kokárna, Sirionó, and Guayakí, show strikingly different grammatical features whose nature must be especially

\footnotetext{
${ }^{1}$ This paper is a revised version of a manuscript written in Brasília, January 1989.
} 
investigated. Cabral (1995) has shown that Kokáma, even though with a Tupí-Guaraní basic lexicon, has a grammar that cannot be derived from Proto-Tupí-Guaraní, what means that it cannot be a member of the TupíGuaraní genetic family. Guayakí and Sirionó (and probably also Horá and Yúki) need yet to be submitted to a thorough study for ascertaining the nature of their divergences.

Some of the grammatical changes to be considered here are clearly consequences of phonological changes. Others are probably due to language contact, particularly with Portuguese in the case of Amazonian Língua Geral.

\section{Nominalization of animate and inanimate subjects}

Chiriguano (also called Áva and Bolivian Guaraní) is a Tupí-Guaraní language spoken in Southeastern Bolivia, Paraguay, and Northern Argentina. It belongs to the same branch I of the family as Guaraní and several dialects of it may be distinguished under the same or other names (e. g. Izozó, Tapiete). Its speakers have been known as invaders in the Inca Empire. The data considered here were published by Schuchard (1979) and Dietrich (1992).

Chiriguano has systematically shifted Proto-Tupí-Guaraní (PTG) stress from the last to the penultimate syllable, has dropped final consonants and, in addition, has changed the PTG phoneme * $c[t s]$ into zero between vowels. ${ }^{2}$ Under the accumulated effect of these three changes, there was a merger of the nominalizing suffixes for animate agent $*_{-a} r \sim-c a ́ r$ and inanimate agent (or circumstance) *-á $\beta \sim-c a ́ \beta$, both reduced phonologically to $-a$. This merger has obscured the opposition between animate and inanimate agents and has enhanced the use of relative nominalization, but only for human referents. Relative nominalization in Tupí-Guaraní languages is a device for nominalizing 3rd person syntatic subjects independently of their pragmatic role and its rnarker in PTG is reconstructed as *- $\beta a$ ?é (or perhaps * $\beta a$ ?é) suffixed to the verb inflected for the third person, and its reflex in Chiriguano is - $\beta a e$. Now Chiriguano has, for instance, mbaépa héi ndéße oporopoanó-

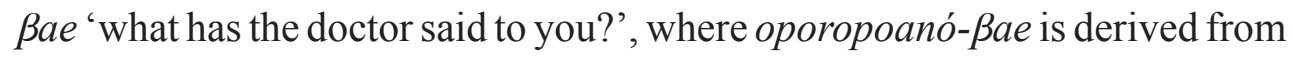
oporopoáno 'he applies medicine' and means litterally 'the one who applies medicine', instead of PTG *moro-pocá-nón-ár-a 'the animate agent (*-ár) of applying (*nól) medicine (*pocán) for humans (*moro-)’(cf. Tupinambá moroposánónára, Old Guaraní poropohánónára, Mbyá Guaraní poropoanõá,

\footnotetext{
${ }^{2}$. The dropping of final consonants and the change $*_{c}>\emptyset$ are shared with other languages of branch I, but the shift of stress to the penultimate syllable is probably due to contact with speakers of Bolivian Kechua.
} 
all for 'doctor'). For non human referents, animals or things, Chiriguano has the nominalizer of agent $-a$ without the addition of the relative nominalizer - $\beta a$ e, as in the following examples: yandúti oisúwa 'a spider's sting' (oisúwa $<\mathrm{PTG} * o-i-c u P W-a ́ \beta-a$ 'action or effect of biting'), ché aiasói asóya-pe 'I cover myself with a blanket' (asóya < *aco?j-á $\beta$ - $a$ 'thing for covering').

\section{From gerundial towards serial verbs and the loss of switch-reference}

In the verbal system of the more conservative Tupí-Guaraní languages the verb of the predicate of a simple sentence or of the first predicate of a complex sentence occurs either in the indicative or in the imperative mood. In these moods, which take no inflectional suffix, the subject is marked by personal prefixes of two sets, one with six forms for the indicative mood and the other with two forms for the imperative. Such forms refer to the grammatical persons or combinations of persons of the subject: 1 'the speaker', $12\left(3^{-\mathrm{f}}\right) / 3^{-\mathrm{f}}$ 'the speaker and the addressee with or without a non focal third person', $123^{+\mathrm{f}} / 3^{+\mathrm{f}}$ 'the speaker and the addressee with one or more focal third persons or only one or more focal third persons', $13^{+\mathrm{f}}$ 'the speaker and one or more focal third persons', 2 'the addressee', $23^{+\mathrm{f}}$ 'the addressee and one or more focal third persons'. For transitive verbs, after the personal prefix for the subject and immediately before the verbal stem, there is a relational prefix referring to the object. While the paradigm of the indicative mood has prefixes for all those six "persons", namely $1 * a-, 12\left(3^{-\mathrm{f}}\right) / 3^{-\mathrm{f}} * j a-, 123^{+\mathrm{f}} / 3^{+\mathrm{f}} o-, 13^{+\mathrm{f}} *$ oro-, $2 *$ ere-, $23^{+\mathrm{f} *}$ pe-, the paradigm of the imperative has only those for $2 * e$ - and $23^{+\mathrm{f}}$ *pe-. Besides the indicative and imperative there are also a co-referential and a non co-referential mood. This latter, morphologically marked by the suffix reconstructed as *-eme - -me, has been called subjunctive and the co-referential, with the suffix *-á $\beta o \sim-\beta o \sim-a \sim(-r \rightarrow \emptyset)$, has been called gerund by the first grammarians of these languages (Anchieta in the $16^{\text {th }}$ century (1595) for Tupinambá and Ruiz de Montoya in the $17^{\text {th }}$ century (1640) for Old Guaraní). The Tupí-Guaranían gerund implies the same subject as that of the indicative in the first or main clause, whereas the subjunctive implies a different subject, so that we can consider these two moods as the two opposite members of a switch-reference system. The gerund has a particular set of personal subjective prefixes in intransitive verbs, but no such prefixes in the transitive ones; these take only referential prefixes making reference to their objects. The subjunctive takes only relational prefixes in both transitive and intransitive verbs, but in the latter they make reference to the subjects. 
The reconstructed Proto-Tupí-Guaraní forms for the personal prefixes of the gerund are: $1 * w i-, 12\left(3^{-\mathrm{f}}\right) / 3^{-\mathrm{f}} * j a-, 123^{+\mathrm{f}} / 3^{+\mathrm{f}} \mathrm{o}-, 13^{+\mathrm{f}} *$ oro-, $2 * e-, 23^{+\mathrm{f}}$ *pe-. With the exception of 1 and 2 these forms are the same as those of the indicative mood, but in the indicative they occur not only in the intransitive, but also in the transitive verbs. For the relational prefixes the reconstructed forms are: ${ }^{*} r-\sim \emptyset$ - 'the referent is the immediately preceding noun', ${ }^{*} c_{-} \sim$ $t-\sim i$ - 'the referent is a not immediately preceding noun'.

Exemplifyiug: Tupinambá, for instance, has a-só kunumĩ pisik-a [1.ind-go boy take-ger] 'I went and took the boy', a-só wi-poraséj- $a$ [1.indgo 1.ger-dance-ger] 'I went and danced', ere-só e-poraséj-a [2.ind-go 2.gerdance-ger] 'you (sg.) went and danced'; but kunumĩ o-só o-poraséj-a [boy 3.ind-go 3.ger-dance-ger] 'the boy went and danced', oro-só oro-poraséj-a [13.ind-go 13.ger-dance-ger] 'we went and danced', pe-só pe-poraséj-a [23. ind-go 23.ger-dance-ger] 'you (p1.) went and danced'. The gerundial mood is used not only for additive clauses, but also for final or purposive ones, so that the first example above may also mean ' 1 went in order to take the boy' and the second example may equally mean 'I went in order to dance'.

\subsection{Chiriguano}

In Chiriguano the changes of stress placement and the loss of final consonants have concurred to the loss of originally unstressed final syllables ( *kutúk > kútu 'to stab', tetáma > tếta 'place') and thus have affected also the gerundial forms ( *kutúka > kútu 'stabbing', ocó $\beta o>$ óho '(he) going'), thereby erasing the phonological difference between the gerundial and the indicative forms for all persons but the lst and 2nd singular of the intransitive verbs, which had different personal prefixes. But analogy has then replaced the gerundial correferential prefixes for 1 and 2 of the intransitives by the corresponding prefixes of the indicative, so that any difference between the two verbal moods disappeared for these verbs. A further analogical step replaced the gerundial forms of the transitive verbs, which had no subject prefixes, by those of the indicative with their own obligatory prefixes. A consequence of all these changes is that Chiriguano has no gerundial form anymore. This notwithstanding, the syntax has only partially changed. For final clauses a new construction is now being employed, namely the prospective form of the relative nominalization (oyápo... ogwápi-wãe-ra 'he made it... in order to sit down', where -wãe-ra $<*_{-} \beta a$ ?e 'norninalizer' $+*_{\text {-ram }}$ 'nominal prospective state'. For additive clauses, no change has occurred, so that now the successive verbs occur in the indicative without any special marking, as in the following examples: $i-f i$ 
o-e ó-ho o-gwáta 'his mother came out and went walking', litt. 'his mother came.out went walked'), kwápe á-iko-ma fe a-kwakwáa 'here I have lived and I have grown up', hãe-ma gwé-ru háwo fúpe, hãe-ma o-mboyakio, hãema o-ãpi, ópa o-ãpi 'he brought (gwé-ru) him (fúpe) soap (háwo), he loused him (o-mboyakio), he cut him the hair (o-ãpi), he cut him (o-ãpi) all the hair' (examples from text in Dietrich 1972). As we see, instead of the gerundial constructions, Chiriguano has now a serial chaining of verbs with the same subject, instead of the common Tupi-Guaranian switch-reference system.

\section{Changes in the pronominal systems}

\subsection{Amazonian Língua Geral}

Amazonian Língua Geral (LGA, also called Nheengatú) evolved from 17lh century Tupinambá (T) as the language of descendants of Tupinambá mothers with Portuguese men in northern Brazil. The offspring of such mixed marriages was in part bilingual in LGA and Portuguese (P) and, although LGA came to be the dominant language of a large population for about 300 years, there has always been bilingual speakers with Portuguese either as a first or as a second language (Rodrigues, 1996).

\subsubsection{Tupinambá and Língua Geral Amazônica}

Tupinambá had three pronouns and three agreeing subject markers for the 'first person plural', one of them excluding the addressee and including a focal third person, the other two including the addressee, and one of these including also a focal third person: oré, oro- ' $1+3^{+\mathrm{f}}$ ', jané, ja- ' $1+2$ ', asé, $o$ - ' $1+2+3^{+\mathrm{f}}$ '. The preflxes $j a$ - and $o$ - agreed also with non-focal third persons $\left(3^{-f}\right)$ and with focal third persons $\left(3^{+f}\right)$, respectively. This fact has been interpreted as reflecting a basic distinction between the existence and the absence of a speaker-addressee contrast in T (Rodrigues 1990). In LGA, only one of these pronouns, jané, survived, having become a universal 'we', just as Portuguese nós. The prefix ja-continued to agree with jané, with the same new universal meaning 'we'; the prefix $o$-, now in some dialects of LGA $u$-, specialized for agreeing only with third person subjects, whereas the prefix oro- disappeared totally together with the corresponding pronoun oré. The end-product of these changes was a personal system more similar to the Portuguese one, with only one pronoun and only one agreeing marker for a universal 'we' (nós and -mos, respectively). 
The similarity of the LGA system with that of $\mathrm{P}$ was enhanced by another change that affected the deictic system of the language. $T$ had a relatively complex system of demonstratives, with several intertwined features, such as proximity to the speaker and proximity to the addressee, visibility, definiteness, anaphoric reference to what was said or meant, and had nominalized forms for each demonstrative. LGA has radically simplified this system, reducing it to a binary opposition between proximity to the speaker-and-addressee and distance from both. In a dialect of LGA fairly well documented (Magalhães 1876) the two demonstratives are kwa?á 'this' and ja?ã 'that'. kwa ?á corresponds to T koßa?é, the nominalized form of kó 'this (near the speaker)' (koßa ?é > *kowa?é > kwa?é > kwa?á); in the Upper Rio Negro dialect, which has lost the glottal stop and contracted adjacent identical vowels, this word is $k w a$ ). The other LGA demonstrative ja? $\tilde{a}$ (Upper Rio Negro $j \tilde{a}$ ) stems probably from a parallel nominalization of $\mathrm{T}$ i’án 'this (near speaker and addressee)', but with a change in its reference. Besides these two demonstratives, LGA has also retained the anaphoric $\mathrm{T}$ a?é 'that one spoken or thought about' as a personal pronoun for the third person, quite parallel in usage to Portuguese ele/ela 'he/she' (Magalhães a?é, Upper Rio Negro aé). The parallelism with Portuguese was increased in LGA by the creation of a plural form a iitá (Upper Rio Negro aitá) 'they' (Portuguese ' eles/elas') with the addition of LGA -itá 'plural marker' (from $\mathrm{T}$-etá '(to be) many'). In T there was no personal pronoun for third person. The consequences of the changes in LGA in comparison with Tupinambá and Portuguese may be overviewed in the table below:

\begin{tabular}{|c|c|c|c|c|c|c|}
\hline \multirow[b]{2}{*}{1} & \multicolumn{2}{|c|}{ Tupinambá } & \multicolumn{2}{|c|}{ LGA } & \multicolumn{2}{|c|}{ Portuguese } \\
\hline & ifé & $a-$ & ifé & $a-$ & $e u$ & $-O$ \\
\hline $12\left(3^{-f}\right)$ & jané & ja- & jané & ja- & nós & $-m o s$ \\
\hline $123^{+f}\left(3^{+f}\right)$ & asé & $O-$ & jané & ja- & nós & $-m o s$ \\
\hline $13^{+\mathrm{f}}$ & ore & oro- & jané & ja- & nós & $-m o s$ \\
\hline 2 & ené & ere-, $e-$ & iné & re- & $t u$ & $-S$ \\
\hline $23^{+f}$ & pe?̃ & pe- & pejẽ & pe- & vós & $-i s$ \\
\hline 3 & & & aré/aé & $u-\sim w_{-}$ & ele/ela & $-\emptyset$ \\
\hline 33 & & & aPitá & $u-\sim w-$ & eles/elas & $-N$ \\
\hline
\end{tabular}


Besides having generalized the use of jané and $j a$ - for all occurrences of 1 with any other person (and consequently having eliminated the pronouns asé and oré), LGA has extended the use of a particular item of the deictic system of PT, *a?é 'that invisible person or thing', for referring to any person in the same way as ele and ela are used in Portuguese (recall that P ele and ela represent also the extension of use of a piece of the deitic system of the Latin language, which had no personal pronoun for 3). On the other hand, in LGA the T stem -etá 'many' came to be used as a marker of plural of the nouns under the influence of the systematic marking of plural in Portuguese nouns. This marker, LGA -itá, was also added to a'é or aé resulting in a Pitá or aitá corresponding to P 'eles' and 'elas'. The result in LGA is a system wholly parallel to that of Portuguese, notwithstanding the contrast of a prefixal with a suffixal inflection.

\subsection{Ka'apór}

Ka'apór (Urubú, Urubú-Ka'apór) is a Tupí-Guaraní language now spoken in western Maranhão state in northern Brazil. Its speakers have formerly lived more to the west, in the Tocantins river valley (Ballée 1994:30ff). In their migration they contacted people speaking LGA and their language has loanwords and other traces of the influence of that language (Corrêa da Silva 1987). The elimination of the distinction in the expression of the combinations of the first with the other persons in the pronouns is probably due to the contact with speakers of LGA. The set of personal pronouns and the corresponding personal prefixes of Ka'apór is the following:

\section{Personal pronouns}

1

12(3)

2

23

3

33

\section{ihe}

jané

ne

pehe

aجe

aجé ta
Personal prefixes

$$
\begin{aligned}
& a- \\
& j a- \\
& r e- \\
& p e- \\
& o-\sim u-\sim w- \\
& o-\sim u-\sim w-
\end{aligned}
$$

As may be easily seen in this set, the pronoun jané and the corresponding prefix $j a$ - have had its meaning extended to all situations 
in which 1 is associated to another person, be it 2 or 3 or a combination of 2 and 3 or of 3 and 3. This is essentially what has happened in LGA, as shown in the preceding section.

Analogously to LGA Ka'apór employs the deictic a é as a personal pronoun for 3, namely a é, and uses a reduced form of the stem -etá 'to be many' for pluralizing this pronoun: a é ta 'they'.

\section{The reduction of the case system}

\subsection{Tupinambá}

Tupinambá had a system of five nominal cases: (a) argumentative (also called onomatic, nominal or nominative) for arguments in a clause, (b) translative (or predicative) for being in or getting into a state, (c) punctual locative for well defined location, (d) diffuse locative for diffuse or spread location, and (e) situational (also called partitive) locative for situation relative to a part of a whole, as in the following paradigms:

\begin{tabular}{|c|c|c|}
\hline & C-ending stems & V-ending stems \\
\hline Stems: & ajúr 'neck' & kuجá 'waist' \\
\hline argumentative & ajúr-a & ku?á- $\emptyset$ \\
\hline transiative & ajúr-amo & kuPá-ramo \\
\hline punctual locative & ajúr-ipe & ku?á-pe \\
\hline diffuse locative & ajúr-ißo & ku?á- $\beta 0$ \\
\hline situational locative & ajúr-i & $k u$ Pá$_{-j}$ \\
\hline
\end{tabular}

\subsection{LGA}

LGA has lost the case system of $\mathrm{T}$ as the result of a conspiracy of quite different changes. In $\mathrm{T}$ the caseless stems worked as existential or possessive predicates, as in tapi?'ir 'it is a tapir' or 'there is a tapir', ne memir 'you have a child' or 'there is a child of yours'. The argumentative case marked the arguments of a predicate, not on $1 y$ the main ones, such as subject and direct object, but also the objects of postpositions, as in ne memir-a tapi?ír-a ojuká ißirásán-a pupé 'your son killed (ojuká) a tapir with a club (ißirásán-a)'. In LGA the predicative use of nouns was replaced by the existential verb of 
$\mathrm{T}$-ikó $\sim-e k o ́$ 'to be in movement' and its comitative-causative derivation -erekó $\sim$-rekó 'to cause something/somebody to be (in movement) with oneself', so that now -ikó (Upper Rio Negro -ikú) is used as a copula and -rekó (Upper Rio Negro -rikú) as a possessive verb 'to have' with two arguments: iné rerekó ne memira 'you have your child'. The caseless forms of Tupinambá disappeared and the argumentative forms became the stem forms in LGA: memira is no more analyzable as memir plus - $a$, having become the unsegmentable word memíra.

The translative case (Tupinambá memíramo) was generally replaced by the new basic form (memira) and partly replaced by the prospective form of the noun (Tupinambá memíráma 'future child', ku?áráma 'future waist'), a replacement favored by the similarity of the endings; but in LGA the prospective form was on its turn reanalyzed as a sequence of a noun and a postposition aráma 'for, in order to' (this postposition having probably originated in the future form of the verbal nominalization for animate agent, ...-ár-ám-a 'one that will ...'). T sje rú $\beta$-a tußi fá $\beta$-amo oikó 'my father is (in the state of) a chief', LGA se pája uikú tui fáwa 'my father is a chief'; T jas-enõj jané r-ußisá $\beta$-amo 'we called him for being our chief', LGA ja-senũj a é jané tui fáwa aráma 'we called him for our chief'.

The punctual localive replaced the diffuse and the situational ones, except for a very few instances that crystallized as adverbial words. On the other hand, in most words the (punctual) locative suffix evolved into a postposition, upé, having as its object the noun in the new unanalyzable form originated $\mathrm{m}$ the argumentative case of T. Instead of T ókipe 'in the house' LGA has úka upé, But the suffix - pe has been retained in words that ended in $-\beta$ in T, a segment that dropped before the suffix: T arg. kisá $\beta-a$ 'hammock', p. loc. kisá-pe 'in the hammock'; LGA kisáwa, kisápe. It has been retained also in some words that took an adverbial character, such as árpe 'on' (T Pári$p e$ 'on the surface'), wirpe 'under' (T wiripe 'in the bottom'). The retention of the locative instead of its replacement by the postposition upé varies according to the dialects of LGA, but the other cases of Tupinambá appear to have totally disappeared from all dialects.

Even though Portuguese is a prepositional language as opposed do the Tupían languages that are postpositional, the strong reduction of the case system in LGA may be seen as the result of a structural influence of the Portuguese language, in the sense of a change from a more synthetic to a more analytic grammatical system. 


\section{References}

Anchieta, Joseph de. 1595. Arte de grammatica da lingua mais usada na costa do Brasil. Coimbra.

Balée, William. 1994. Footprints of the forest: Ka'apor ethnobotany - the historical ecology of plant utilization by an Amazonian people. New York: Columbia University Press.

Cabral, Ana Suelly A. C. 1995. Contact-induced language change in the western Amazon: The non-genetic origin of the Kokama language. Ph.D. dissertation, University of Pittsburgh.

Corrêa da Silva, Beatriz. 1997. Urubú-Ka'apór, da gramática à história: a trajetória de um povo. Master Thesis, Universidade de Brasília.

Dietrich, Wolf. 1990. More evidence for an internal classification of TupiGuaraní languages. Indiana, supplement 12. Berlin: Gebr. Mann.

Dietrich, Wolf. 1992. El idioma Chiriguano: gramática, textos, vocabulario. Madrid: Instituto de Cooperación Iberoamericana.

Rodrigues, Aryon D. 1985. Relações internas na família linguística TupiGuaraní. Revista de Antropologia 27/28:33-53. São Paulo.

Rodrigues, Aryon D. 1990. You and I = neither you nor I: the personal system of Tupinambá. In: Doris L. Payne (ed.), Amazonian linguistics: studies in lowland South American languages. Austin: University of Texas Press, pp. 393-405.

Rodrigues, Aryon D, 1996. Argumento e predicado em Tupinambá. Boletim da Associação Brasileira de Lingüística 19:57-66.

Ruiz, Antonio. 1640. Arte, bocabulario de la lengua Guaraní. Madrid.

Schuchardt 1979. Nande ñë: gramática Guaraní para Castellano hablantes. Santa Cruz de la Sierra. 